\title{
Pemijahan Ikan Endemik Pelangi Arfak (Melanotaenia Arfakensis) Secara Alami
}

\author{
Natural Spawning of Endemic Arfak Rainbowfish (Melanotaenia Arfakensis) \\ Vicky Arnold Mofu ${ }^{1}$, Bayu Pranata ${ }^{2}$, Marhan Manaf ${ }^{3}$ \\ ${ }^{1,2,3}$ Program Studi Budidaya Perikanan, Fakultas Perikanan dan Ilmu Kelautan Universitas Papua
}

\section{ARTICLE INFO \\ Article history: \\ DOI: \\ $\underline{10.30595 / \text { pspfs.v2i.164 }}$}

Submitted:

July 29, 2021

Accepted:

Sept 10, 2021

Published:

Nov 10, 2021

\section{Keywords:}

Endemic, Melanotaenia

Arfakensis, Arfak Rainbowfish

\begin{abstract}
Arfak rainbowfish (Melanotaenia arfakensis) is one of the endemic fish of West Papua that can be found in river and lake systems in the Manokwari Regency. Currently, the status of the arfak rainbowfish is nearly extinct. Therefore, this study aimed to know the hatching rate and survival of arfak rainbowfish larvae that were naturally spawned. The results showed that the hatchability of arfak rainbowfish eggs reached $96.9 \%$ in A1 aquarium and $96.4 \%$ in A2 aquarium. The survival rate of arfak rainbowfish larvae in the $\mathrm{A} 1$ aquarium was $67.5 \%$, while the A2 aquarium was $58.7 \%$. The larval survival rate was relatively low. Therefore, further research is needed to increase the survival rate of arfak rainbowfish larvae.
\end{abstract}

This work is licensed under a Creative Commons Attribution 4.0 International License.

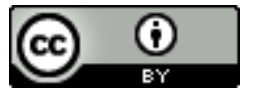

\author{
Corresponding Author: \\ Bayu Pranata \\ Program Studi Budidaya Perikanan, Fakultas Perikanan dan Ilmu Kelautan \\ Universitas Papua \\ Email: b.pranata@unipa.ac.id
}

\section{PENDAHULUAN}

Ikan pelangi arfak (Melanotaenia arfakensis) merupakan salah satu ikan endemik Papua Barat, Kabupaten Manokwari (Allen, 1991). Ikan pelangi arfak atau dalam bahasa inggris disebut Rainbowfish merupakan jenis ikan hias. Masyarakat Suku Arfak dalam Bahasa Hatam menyebut ikan tersebut dengan nama "Anggicak". Ikan pelangi arfak dapat ditemukan pada sistem sungai di Kabupaten Manokwari (Manangkalangi et al., 2018).

Saat ini, status konservasi ikan pelangi arfak yaitu terancam punah (Endangered) (Allen dan Kadarusman, 2020). Pola penyebaran populasi ikan pelangi arfak yang terbatas dan sangat rentan terhadap kepunahan akibat degradasi kualitas habitat alami. Pembukaan lahan perkebunan kelapa sawit dan kegiatan pertanian yang mengubah hutan riparian disekitar sungai menyebabkan terjadi degradasi habitat (Allen, 1991).

Oleh karena itu, perlu dilakukan suatu usaha untuk melestarikan sumberdaya ikan endemik tersebut. Salah satunya dengan mengkaji secara ilmiah teknik pemijahan ikan pelangi arfak secara alami. Informasi ini penting untuk menunjang pengembangan budidaya ikan pelangi arfak kedepanya. Tujuan dari penelitian ini yaitu untuk mengetahui daya tetas telur dan tingkat kelangsungan hidup larva ikan pelangi arfak yang dipijahkan secara alami.

\section{METODE PENELITIAN}

Penelitian dilaksanakan padan bulan Ferbruari sampai April 2021. Lokasi penelitian yaitu di Laboratorium 
Akuakultur dan Kualitas Air, Jurusan Perikanan, Fakultas Perikanan dan Ilmu Kelautan, Universitas Papua.

\section{Bahan}

Adapun bahan-bahan yang digunakan yaitu 4 individu jantan dan 8 individu betina ikan pelangi arfak, pakan pellet dan kuning telur.

\section{Alat}

Alat utama yang digunakan yaitu dua buah akuarium, kakaban yang terbuat dari tali rafia, aerator (Amara Aquarium Air Pump Bs 410), timbangan, penggaris (120mm Carbon Steel Vernier Caliper), pH meter (LUTRON PH-220S Soil pH Meter) dan DO meter (Lutron DO-5510 Dissolved Oxygen Meter x000d).

\section{Indukan Ikan Pelangi Arfak}

Induk ikan pelangi arfak yang digunakan telah dewasa dan matang gonad. Jumlah induk sebanyak 12 ekor. Terdiri dari 4 individu induk jantan dengan bobot rata-rata 72 gram/ekor dan 8 induk betina dengan bobot ratarata yaitu 41 gram/ekor. Panjang tubuh induk jantan 6-9,5 cm/ekor dan induk betina 6,3-10,5 cm/ekor. Pemijahan ikan pelangi arfak dilakukan secara alami dengan perbandingan antara induk jantan dan betina yaitu $2: 4$ antara dua induk jantan dan empat induk betina.

\section{Wadah Pemijahan}

Wadah pemijahan yang digunakan yaitu dua buah akuarium. Ukuran akuarium 1 (A1) yaitu panjang $60 \mathrm{~cm}$, lebar $30 \mathrm{~cm}$ dan tinggi $30 \mathrm{~cm}$, sedangkan akuarium 2 (A2) yaitu panjang $60 \mathrm{~cm}$, lebar $40 \mathrm{~cm}$ dan tinggi $40 \mathrm{~cm}$. Pada masing-masing akuarium diberikan aerasi serta kakaban yang terbuat dari tali rafia sebagai media untuk menempelkan telur.

\section{Pakan}

Jumlah pakan yang diberikan selama masa pemeliharaan induk ikan pelangi arfak yaitu adalah 0,14-0,15 gram dengan kandungan protein 20\%. Pakan pellet yang diberikan terlebih dahulu dihalus sehingga sesuai dengan bukaan mulut ikan pelangi arfak. Frekuensi pemberian pakan tiga kali sehari yaitu pada pagi hari pukul 08.00 WIT, siang hari pukul 14.00 WIT dan pada sore hari pukul 16.00 WIT. Pemberian pakan dilakukan secara adlibitum atau pemberian pakan sampai ikan kenyang.

Sedangkan pakan untuk larva ikan pelangi arfak yaitu kuning telur yang direbus lalu diberikan pada larva. Selain itu, larva diberi pakan alami seperti infusoria. Setelah larva ikan rainbow sudah mulai berumur $2-4$ minggu, larva diberi pakan pellet yang telah dihaluskan sesuai bukaan mulut. Pakan diberikan 3x sehari yaitu pagi, jam 07.30, siang 14.00 dan sore hari pukul 16.00 WIT. Pemberian pakan dilakukan dengan cara diberikan sedikit demi sedikit hingga larva ikan rainbow kenyang atau sudah tidak mau makan lagi.

\section{Analisis Data}

a. Hatching Rate (HR)

Hatching rate (HR) adalah daya tetas telur atau jumlah telur yang menetas. Untuk medapatkan nilai SR, menggunakan persamaan sebagai berikut (Effendi, 2002).

$$
\mathrm{HR}=\frac{\text { Jumlah telur yang menetas }}{\text { Jumlah total telur }} \times 100 \%
$$

\section{b. Survival Rate (SR)}

Survival rate adalah perbandingan jumlah individu yang hidup pada akhir pemeliharaan dari jumlah awal. SR merupakan presentase kelulusanhidup ikan, SR dapat di hitung menggunakan rumus dari Zonneveld et al. (1991) yaitu sebagai berikut:

$\mathrm{SR}=\frac{N_{t}}{N_{o}} \times 100 \%$

Keterangan:

$\mathrm{SR}=$ Survival Rate

$\mathrm{Nt}=$ Jumlah kultivan pada akhir pemeliharaan

$\mathrm{No}=$ Jumlah kultivan pada awal pemeliharaan

\section{HASIL DAN PEMBAHASAN}

Pemijahan dalam kegiatan budidaya bertujuan untuk melestarikan serta mendapatkan benih dan calon indukkan yang berkualitas unggul. Teknik pemijahan dapat dilakukan secara buatan dan alami. Dalam penelitian 
ini, pemijahan ikan pelangi arfak dilakukan secara alami dengan perbandingan antara induk jantan dan betina yaitu 1:2, pada masing-masing akuarium yaitu terdiri dari 2 induk jantan dan 4 induk betina.

Ukuran kali pertama matang kelamin pada ikan pelangi arfak jantan dan betina yang matang kelamin, yaitu: panjang baku 23,65 mm pada individu jantan dan panjang baku 25,40 mm pada individu betina. Pada ukuran yang dewasa, karakter seksual sekunder, mulai terlihat jelas terkait kecerahan warna dan tinggi tubuh yang lebih tinggi pada individu jantan (Manangkalangi et al., 2018). Deskripsi ikan pelangi arfak yang siap memijah (TKG V) secara morfologis dan histologis yaitu testes berwarna putih, berukuran lebih besar, bentuknya memanjang dan pejal. Ovari berwarna oranye-kuning dan telur-telur membulat dengan jelas terlihat. Testes pada tahap ini didominasi oleh spermatozoa. Oosit pada tahap ini ditandai dengan berakhirnya pembentukan kuning telur dan terjadi penyatuan di antaranya sehingga terlihat sebagai massa kuning telur yang relatif homogen dalam oosit (Manangkalangi et al., 2009).

Bedasarkan hasil pengamatan, pemijahan ikan pelangi arfak berlangsung pada malam hingga menjelang pagi hari dicirikan dengan induk jantan akan mengejar induk betina sampai kesudut akuarium dan menghalangi pergerakan dari induk betina. Ikan pelangi arfak biasanya melakukan proses perkawinan sehari setelah pemasangan induk jantan dan betina serta aktif memijah pada pagi hari, namun pada siang hari juga dapat terjadi pemijahan (Chumaidi et al., 2009).

Ikan pelangi arfak mengeluarkan telur secara bertahap. Hal serupa terjadi pada ikan pelangi kurumoi, telur yang terbuahi tidak langsung dikeluarkan sekaligus tetapi dikeluarkan secara bertahap sedikit demi sedikit bergitu pula proses penetasannya (Nur et al, 2011). Telur ikan pelangi arfak memiliki sejenis benang yang bisa menempel pada substrat, ukuran dari telur ikan pelangi arfak ini sangat kecil dan rentang terkena jamur yang bisa mengakibatkan kegagalan dalam penetasan telur. Hasil penelitian Manangkalangi et al (2009) menunjukkan bahwa ukuran diameter telur ikan pelangi arfak bervariasi di antara 0,5 dan 1,3 mm.

Jumlah telur ikan pelangi arfak pada akuarium A1 yaitu sebanyak 194 butir telur, sedangkan akuarium A2 sebanyak 113 butir telur, hasil pengamatan selama 7 hari. Setelah 7 hari, dilakukan pengamatan dan perhitungan terhadap telur yang menetas, hasil pengamatan menunjukkan bahwa akuarium A yaitu 188 ekor larva dan akuarium A2 yaitu 109 ekor larva. Derajat penetasan (hatching rate) selama proses pemijahan ikan pelangi arfak cukup baik, dengan hasil yang mencapai 96,9\% pada akuarium A1 dan 96,4\% pada akuarium A2. Hal serupa juga ditemukan oleh Kadarini (2011) yaitu telur akan menetas setelah 5-6 hari dengan daya tetas hingga mencapai 95\%. Daya tetas telur yang diperoleh dipengaruhi oleh beberapa faktor yaitu kualitas telur yang dihasilkan dari induk yang berbeda, penyakit (Yuliani et al., 2013). Telur yang tidak berhasil menetas berwarna putih susu, sedangkan telur yang akan menetas terlihat berwarna putih bening (Kadarini, 2011).

Pada umur satu minggu, rata-rata ukuran larva ikan pelangi arfak pada akuarium A1 yaitu 4,948 mm, sedangkan akuarium A2 yaitu 4,863 mm. Setelah umur 2-4 minggu, rata-rata ukuran larva ikan pelangi arfak pada akuarium A1 yaitu $15.693 \mathrm{~mm}$, sedangkan akuarium A2 yaitu $12.452 \mathrm{~mm}$.
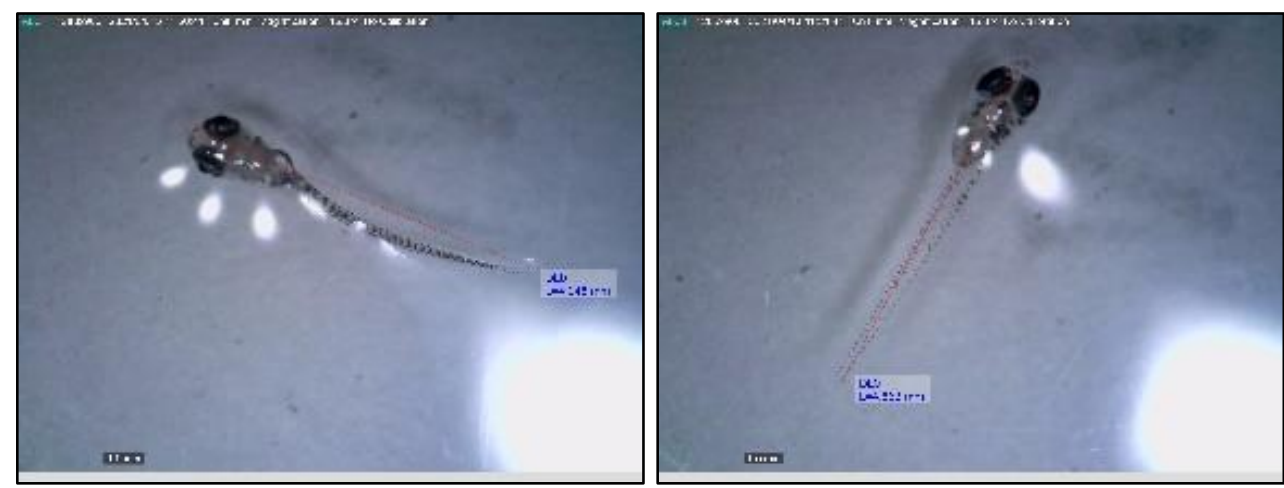

Gambar 1. Larva Ikan Pelangi Arfak pada Umur Satu Minggu 

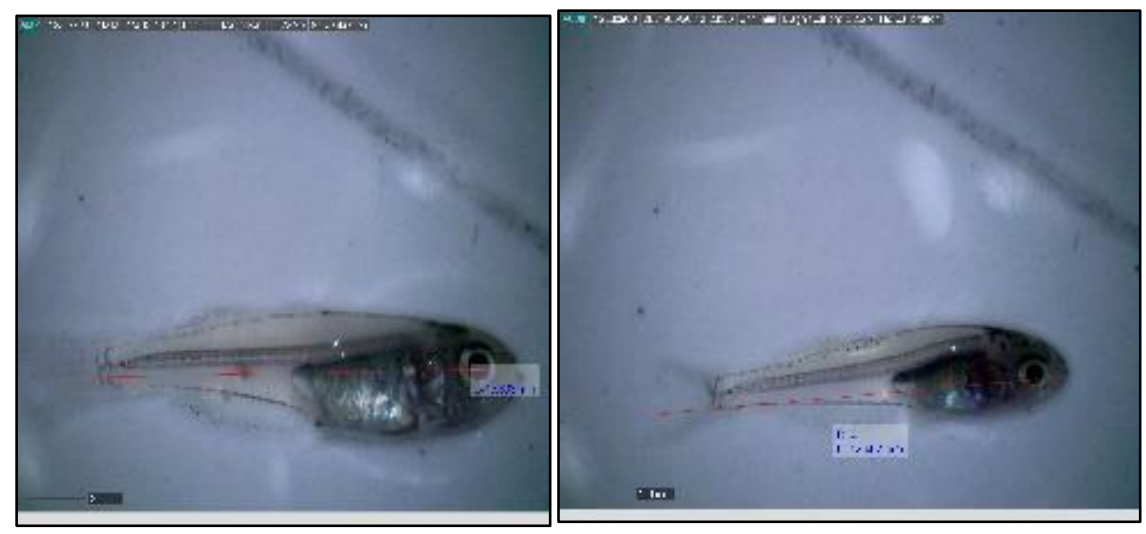

Gambar 2. Larva Ikan Pelangi Arfak Umur 2-4 Minggu

Larva ikan pelangi arfak mulai kehabisan kuning telur pada berumur 3-4 hari setelah menetas. Ketika kuning telurnya telah habis larva harus diberikan pakan yang sesuai dengan bukaan mulutnya. Pakan yang diberikan yaitu kuning telur yang direbus lalu diberikan pada larva. Selain itu, diberikan pakan alami seperti infusoria. Pada umur larva 2-4 minggu diberi pakan pellet yang telah dihaluskan sesuai bukaan mulut larva. Pemberian pakan diberikan 3x sehari yaitu pagi, jam 07.30, siang 14.00 dan sore hari pukul 16.00 WIT. Pemberian pakan dilakukan dengan cara diberi sedikit demi sedikit hingga larva ikan rainbow kenyang atau sudah tidak mau makan lagi. Selama masa pemeliharaan larva ikan pelangi arfak dilakukan pengamatan kelangsungan hidup larva. Tingkat kelangsungan hidup pada akuarium A1 yaitu $67.5 \%$, sedangkan akuarium A2 yaitu $58.7 \%$.

Faktor fisik-kimiawi perairan merupakan faktor penting dalam mendukung kelangsungan hidup ikan. Ikan pelangi arfak cenderung berada pada habitat dengan suhu air yang cukup dingin, kondisi air yang jernih, oksigen terlarut yang cukup tinggi, dan cenderung normal-basa (Manangkalangi et al., 2018). Karakteristik habitat ikan pelangi arfak, yang meliputi parameter fisik-kimiawi, yaitu: suhu air $\left(22,1-28,6{ }^{\circ} \mathrm{C}\right)$, kekeruhan $(<58,1 \mathrm{NTU})$, konsentrasi gas oksigen terlarut (3,2- 7,9 mg. $\left.\mathrm{l}^{-1}\right)$, dan $\mathrm{pH}$ air $(6,3-8,8)$ (Manangkalangi et al., 2018; Manangkalangi et al., 2014). Hasil pengukuran parameter kualitas air selama pemeliharaan yaitu suhu (25.0$\left.27.5^{\circ} \mathrm{C}\right)$, oksigen terlarut $\left(5,5-8,2 \mathrm{mg} \cdot \mathrm{l}^{-1}\right)$ dan $\mathrm{pH}$ air $(7,46-8,92)$.

\section{KESIMPULAN}

Pembenihan ikan pelangi arfak secara alami sangat potensial untuk dikembangkan. Hasil pengamatan daya tetas telur sangat baik, yaitu mencapai 96,9\% pada A1 dan 96,4\% pada A2. Namun, perlu kajian lebih lanjut untuk meningkatkan kelangsungan hidup larva selama proses pemeliharaan.

\section{DAFTAR PUSTAKA}

Allen, G.R. (1991). Field guide to the freshwater fishes of New Guinea. Christensen Research Institute. Madang. PNG.

Allen, G.R. \& Kadarusman. (2020). Melanotaenia arfakensis. The IUCN Red List of Threatened Species 2020:e.T13057A147688392. https://dx.doi.org 3.RLTS.T13057A147688392.en.

Chumaidi, Nur, B., Sudarto, Pouyaud, L., \& Slembrouck J. (2009). Pemijahan dan perkembangan embrio ikan pelangi, Melanotaeenia spp. asal Papua. Jurnal Perikanan. 11(2): 131-137.

Effendie, M. I. 2002. Biologi Perikanan. Yayasan Pustaka Nusantara. Yogyakarta. 163 hlm.

Manangkalangi, E., Rahardjo, M.F., Sjafii, D.S., \& Sulistiono. (2009). Musim pemijahan ikan pelangi arfak (Melanotaenia arfakensis Allen) di Sungai Nimbai dan Sungai Aimasi, Ma-nokwari. Jurnal Iktiologi Indonesia, 9 (1): 1-12.

Manangkalangi, E., Leatemia, S.P.O., Lefaan, P.Th. (2014). Kondisi habitat ikan pelangi arfak, Melanotaenia arfakensis Allen, 1990 di Sungai Nimbai, Prafi Manokwari. Jurnal Iktiologi Indonesia, 14(1):21-36.

Manangkalangi, E., Rahardjo, M.F., Hadianty, R.K., \& Hariyadi, S. (2018). Ikan Endemik di Indonesia: Melanotaenia arfakensis Allen, 1990. WARTA IKTIOLOGI, Vol 2(1): 11-17.

Nur, B., Chumaidi, Sudarto, Pouyaud, L., \& Slembrouck, J. (2009). Pemijahan dan Perkembangan Embrio Ikan 
Pelangi (Melanotaenia spp.) Asal Sungai Sawiat, Papua. Jurnal Riset Akuakultur, Vol 4, No 2: hal 147156.

Nur, B., Sudarto, Darti Satyani, dan Gigih Setia Wibawa, 2011. Viabilitas Reproduksi dan Pertumbuhan Ikan Pelangi Ajamaru (Melanotaenia ajamarunensis Allen \& Cross). Prosiding Forum Inovasi Teknologi Akuakultur 2011.

Kadarini, T., Mertayasa, A., \& Kusrini, E. (2011). Dukungan Pembenihan Ikan Rainbow Boesemani (Melanotaenia boesemani) Terhadap Sumber Daya Ikan di Depok. Prosiding Forum Nasional Pemacu Sumber Daya Ikan III. Bandung.

Yuliani, F., Kadarini, T., \& Elfidasari, D. (2013) Produksi Larva Ikan Rainbow Kurumoi (Melanotaenia parva) di Balai Penelitian dan Pengembangan Budidaya Ikan Hias Depok, Jawa Barat. Prosiding Seminar Nasional Biologi-IPA 2013- ISBN: 978-979-028-573-6 Surabaya, 2013: halaman 48-51.

Zonneveld, N., Huisman E. A, \& Boon, J. H. 1991. Prinsip-Prinsip Budidaya Ikan. Gramedia Pustaka Utama. Jakarta. 318 hlm. 